A FUTURE PERSPECTIVE ON CONSTITUTIONAL STABILITY

ISSN 1727-3781

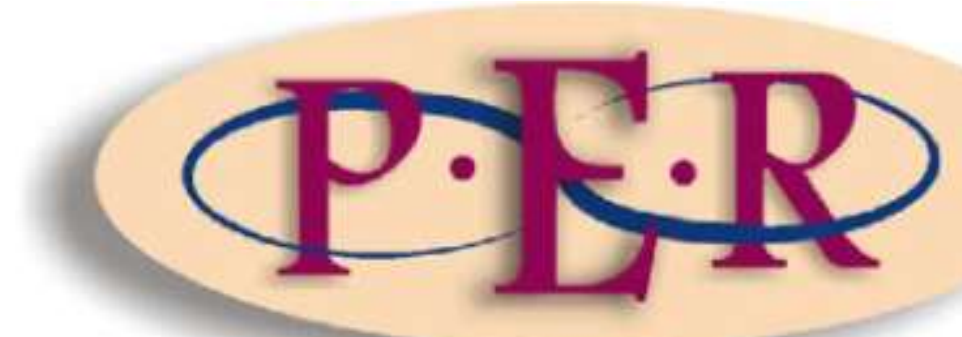

2010 VOLUME 13 No 2 


\section{A FUTURE PERSPECTIVE ON CONSTITUTIONAL STABILITY ${ }^{\star}$}

\section{FW de Klerk}

The $2^{\text {nd }}$ of February next year will be the twentieth anniversary of the beginning of the transformation process that led to the establishment of our present non-racial constitutional democracy. The previous year when I had addressed the National Party caucus after my unexpected election as leader of the party, I stressed the need to take a quantum leap to break out of the political and economic dead-end street in which we found ourselves. The overwhelming reaction was "jump FW, jump!".

And so, twenty years ago, we took our calculated leap of faith. We reasoned that it was unlikely that there would ever again be such favourable circumstances for a settlement:

- $\quad$ after the fall of the Berlin Wall, global Communism was in headlong disarray;

- $\quad$ the South African Communist Party - which had controlled virtually all the seats on the ANC's National Executive Committee during the 1980s - was in shell-shocked retreat;

- after the failure of the 1984-1987 offensive to make South Africa ungovernable, the ANC had at last accepted that there would not be a revolutionary outcome;

- $\quad$ all parties accepted that the continuing escalation of conflict would simply destroy the economy and any hope of building a united future; and

- $\quad$ in the September 1989 elections, the white electorate had given the National Party a clear mandate for comprehensive reform and negotiations.

Never again would the balance of forces be so favourable for a fair, negotiated settlement. Even so, we did not enter the negotiation process blindly.

* $\quad$ Speech at the eighth FW de Klerk lecture, North-West University, Potchefstroom Campus, on 12 October 2009.

** $\quad$ Frederik Willem de Klerk, former State President of the Republic of South Africa. 
- We had already held informal and extensive exploratory talks with the ANC and with Nelson Mandela.

- We were confident that we would be able to negotiate a constitution that would protect the reasonable rights of all South Africans - a constitution that would address the concerns of those who had much to lose, as well as the aspirations of those who had much to gain.

- All this was taking place within an evolving global environment in which constitutional democracy and free-market principles were triumphant. The reality was that no major economy could afford to ignore the growing consensus on these principles. Those countries - like Zimbabwe, Cuba and North Korea that did ignore them - paid an enormous price.

- There was also acceptance that the need to foster unity amongst our diverse population groups would inevitably place constraints on whatever new government might emerge from the negotiation process.

The negotiations culminated on 21 December 1993 with the adoption of the Interim Constitution ${ }^{1}$, which provided the basis for South Africa's first universal democratic election in April 1994. It also established the framework for the drafting and adoption of a final constitution by the duly elected Parliament sitting as a Constitutional Assembly. Most importantly, the new constitution would have to comply with thirtyfive constitutional principles that had been negotiated into the 1993 Constitution. The Constitutional Assembly duly drafted and adopted the final Constitution of the Republic of South Africa, $1996^{2}$ in 1996 and submitted it to the newly established Constitutional Court for certification. Only on 4 February 1997, after the Court was fully satisfied that the new Constitution complied in all respects with the thirty-five constitutional principles, did the new Constitution come into effect.

1 Constitution of the Republic of South Africa, 200 of 1993 (hereafter 1993 Constitution).

2 Hereafter the Constitution. 
Since then the Constitution has in a very real sense been the foundation of our new society:

- it articulates the values on which the new South Africa has been founded;

- $\quad$ it expresses the transformational aspirations for human dignity, equality and social justice for which we all should strive;

- $\quad$ it lists the rights that all our citizens must enjoy; and

- $\quad$ it provides truly democratic principles for the organisation of the State, including an executive responsible to a democratically elected legislature and an independent judiciary standing guard over the Constitution, the rule of law and the Bill of Rights. ${ }^{3}$

The Constitution was nevertheless a great historic compromise. No party achieved everything that it wanted - but all parties were able to secure their minimum demands. Some wanted a unitary state; others, a federation; some wanted unbridled power to expropriate property; others were deeply concerned about the future of their homes and businesses. Some wanted a single South African identity; others insisted on retaining our rich cultural and language diversity. We were able to reach compromises regarding all of these critical issues, many of which were very delicately balanced.

So, for South Africa, our Constitution is much more than a handbook on managing the mechanisms of democracy or protecting basic human rights. In the words of the preamble, it is enabling us to heal the divisions of the past and to establish a society based on democratic values, social justice and fundamental human rights.

In short, the Constitution is the indispensable basis of our national unity and our best and abiding hope for continued freedom, prosperity and stability. For all these reasons, we dare not allow anyone to undermine or threaten it. Yet, the Constitution is under threat - and I believe that it is under threat on seven different fronts. 
The first threat is the possibility that Parliament might legally amend the Constitution. In terms of Section 74, Parliament may amend any provision of the Bill of Rights and the body of the Constitution itself with a two-thirds majority in both the National Assembly and the National Council of Provinces and with the support of six of the nine provinces. It is important to note, however, that Parliament may amend the founding provisions in Section 1 only with a $75 \%$ majority. In other words, Parliament has only a very constrained ability to amend any provision that would undermine the basic institutions of democracy; the supremacy of the law; and the values of non-racialism, human dignity, equality and the advancement of human rights and freedoms.

To its credit, the Government has shown little inclination to introduce substantive amendments to the Constitution - even though it enjoyed for several years the necessary two-thirds majority to do so. The exceptions are the Constitution Fourteenth Amendment Bill ${ }^{4}$ and the Constitution Seventeenth Amendment Bill, ${ }^{5}$ which is currently before Parliament.

The Constitution Fourteenth Amendment Bill, which was introduced at the end of 2005, would have seriously undermined key aspects of the independence of the judiciary. Fortunately, the Government withdrew the Bill the following year after it encountered vehement and resolute opposition from jurists and commentators across the political spectrum.

The second exception is the Constitution Seventeenth Amendment Bill, which has far-reaching implications for the future autonomy and viability of the municipal government. Under the guise of an initiative to ensure more effective electricity distribution, the Bill would in effect give Government at the national level the power to intervene in a wide range of municipal functions. By so doing, it would undermine one of the key compromises in the Constitution and would set a precedent that might affect the autonomy of provinces as well. 
The second threat comes from the process of legislative erosion. In this process, constitutional rights are progressively whittled away by provisions hidden away in ordinary legislation. So, for example, the Expropriation Bill ${ }^{6}$ that was presented to Parliament last year would have seriously limited the role of courts in determining fair compensation for expropriated property. By so doing it would have eroded constitutional rights to fair administrative action and to access to the courts. Fortunately, the Bill was withdrawn.

There were similar problems last year with the National Prosecuting Authority Amendment $\mathrm{Act}^{7}$ and South African Police Services Amendment Act, ${ }^{8}$ which abolished the Scorpions and established a new unit in the South African Police Services to combat serious crime. Critics believe that the legislation undermined the constitutionally guaranteed independence of the National Prosecuting Authority and deprived it of its power under the constitution of carrying out "any necessary functions incidental to instituting criminal proceedings."

In the same manner, the recently adopted Films and Publications Amendment Act ${ }^{9}$ undermines aspects of the constitutionally guaranteed right to freedom of expression. In the opinion of critics, it deviates from the carefully worded text of the Constitution's definition of impermissible communication; it is unacceptably vague; it creates unequal conditions for media that belong to recognised media organisations and those that do not; and it requires some media to go through the impossible task of submitting their material to censors before it is published.

The third threat to the Constitution comes from executive neglect. In terms of this practice, the Executive simply does not bother with elements of the Constitution that it does not like. This is particularly apparent in the manner in which the Constitution's language and cultural provisions have been systematically ignored since 1994.

6 GN 440 in GG 30963 of 11 April 2008.

756 of 2008.

857 of 2008.

93 of 2009. 
The Constitution spells out the following requirements with regard to language and culture:

- It recognises our eleven official languages.

- It requires the State to take special action to develop our indigenous languages.

- It requires Government at national and provincial levels to use two official languages.

- It states that municipalities must take into account the language preferences of residents.

- It requires national and provincial governments to regulate and monitor their use of official languages.

- It requires that all official languages enjoy parity of esteem and be treated equitably.

- It states that all South Africans have the right to receive education in the language or languages of their choice in public educational institutions, where such education is reasonably practicable.

Unfortunately, virtually every one of these provisions has been ignored or diluted since the adoption of the Constitution, 1996:

- $\quad$ Increasingly, we have a single de facto official language - English.

- $\quad$ Government is not conducted in two official languages.

- Our languages do not enjoy parity of esteem - and are not treated equitably.

- $\quad$ Little or nothing has been done to develop our indigenous languages.

- Afrikaans single-medium schools are under pressure and there is serious concern regarding the preservation of Afrikaans as the primary language of tuition at Stellenbosch University.

The fourth threat to the Constitution comes from executive incapacity. In many areas, the State appears to be incapable of effectively ensuring key rights because of the crisis that it is experiencing with service delivery. 
The unhappy reality is that:

- $\quad$ rampant violent crime too often deprives people of their right to life, their right to be free from all forms of violence, and their right to property;

- $\quad$ the right to equality has been negated by the fact that after fifteen years, we are still one of the most unequal societies in the world - the State has not adopted appropriate legislative and other measures to protect and advance persons disadvantaged by unfair discrimination; the appropriate measures are not unbalanced affirmative action but decent education, effective service delivery and job creation;

- $\quad$ the rights of children are not properly respected - as is illustrated by high levels of abuse and neglect, and the existence of so many street children and child-headed households

- $\quad$ the right to basic education has been seriously limited by the failure to deliver decent education; and

- too many people do not, in practice, enjoy adequate access to the courts or to a trial without unreasonable delay.

The provision of effective education, policing and health services is an essential requirement for the achievement of constitutional rights.

The fifth threat comes from the possibility that the Constitution might increasingly be interpreted by the courts to favour the executive or a single section of our society. I must stress that this has not yet happened. The courts have on the whole given judgments that are independent and impartial. The new Chief Justice has convincingly expressed his commitment to uphold the independence of the judiciary and of the Constitution.

However, we cannot ignore the call by the ANC's National Executive Committee in 2005 to bring "the collective mindset of the judiciary" ... "into consonance with the vision and aspirations of the millions who engaged in struggle to liberate our country from white minority domination". Given this approach, the threat remains that the 
executive might progressively try to ensure that like-minded judges are appointed to the bench.

It is perfectly acceptable in South Africa - and in other countries with respected judicial traditions - that elected governments will and should ensure that the bench keeps pace with changing public values and attitudes. However, there are limits to the permissible political evolution of the judiciary - particularly in multicultural societies like our own.

The convention on which democracy rests is that questions of political power will not be settled by destructive and divisive conflict but through free and fair elections. The indispensable corollary is that winners of elections must respect the civil and political rights of the losers. This process must be regulated by constitutions and bills of rights, and must be adjudicated by fair and independent courts. In effect, constitutions are written primarily to protect the interests of disempowered minorities and individuals - since majorities can usually use their control of state power to secure their own interests. In the case of South Africa, it is particularly important that the political evolution of the judiciary not be permitted to undermine the carefully constructed constitutional consensus on which our new society was founded.

Many constitutional rights are carefully balanced with countervailing rights. There is a right to property - but there is also a right to land reform; there is freedom from discrimination - but there is also sanction for legislative and other measures to advance those who were disadvantaged through unfair discrimination. There is a right to education in the language of one's choice - but it must be practicable, equitable and non-racial. There is a right to use one's language and culture - but not in a manner that will undermine the rights of others. Should the courts consistently deliver judgments in favour of just one side of the balance, the carefully constructed compromises at the heart of our constitution would be destroyed - and with them prospects for national unity and stability.

The sixth threat to the Constitution comes from the prospect of political subversion. The lesson of the ANC's $52^{\text {nd }}$ National Conference at Polokwane was that power, to its mind, does not reside in the Constitution or with Parliament, the executive and the 
judiciary. It rests, instead, according to the ANC left wing, in the hands of whichever group can gain control of the majority party in Parliament. This is because Section 47(3)(c) of the Constitution stipulates that members of Parliament lose their membership of Parliament if the party to which they belong rescinds their party membership. Our parliamentary representatives are accordingly not primarily accountable to the electorate - but to the bosses of their respective parties.

At Polokwane, the ability of factions opposed to President Mbeki to swing just $10 \%$ of the votes resulted in a complete shift in national political power. The new party leadership - which had not been elected by the public - decided what the legislative programme of Parliament should be, dictated who should be appointed to key political posts and, ultimately, fired the President.

Accordingly, it is just as important to observe the power relationships within the leadership of the ruling party as it is to watch the public display of party politics in the broader national arena. In particular, we need to monitor the shifting relationships within the ANC/SACP/COSATU Alliance. We should bear the following in mind:

- $\quad$ COSATU subscribes to the SACP's political vision - so from a political point of view, it should really be the ANC/SACP Alliance. Both the SACP and COSATU are committed to building "Marxism-Leninism as a tool of scientific inquiry to search for answers in the contemporary world".

- COSATU and the SACP support the ANC's doctrine of the National Democratic Revolution - but only as a basis for further progress toward the achievement of their medium-term vision "to secure working class hegemony in the State in its diversity and in all other sites of power". Their long-term vision is to build 'Socialism', that is, a fully-fledged Communist state.

- The SACP has called for the "reconfiguration of the Alliance" by means of the establishment of an Alliance Political Council "to oversee broad political issues". The ANC and COSATU would each have six members on the Council and the SACP, modestly, would have five. 
- The SACP had eighty members in the last Parliament who were elected on the ANC's list. This was twenty per cent of total representation, despite the fact that opinion polls show that the SACP and COSATU combined would have no more than eight per cent of the vote. Nevertheless, the SACP insists its members of Parliament who are elected on the ANC's list should continue to owe their primary loyalty to the SACP.

- The SACP has abandoned the idea of standing separately in elections and has observed that "although elections are important, there is not a predetermined singular route for the working class to hegemonise power." In other words, they plan to achieve power through other means.

- $\quad$ At its Twelfth Congress in July 2007, the SACP quoted with approval the long-standing instruction of the Communist party of the Soviet Union that the SACP should concentrate on "developing systematically the leadership of the workers and the Communist Party in this organisation", that is the ANC.

In the last few weeks, we have seen COSATU and the SACP launch a full frontal attack on Minister Trevor Manuel because they believe that his recently published Green Paper on National Strategic Planning ${ }^{10}$ presages a return to the broad economic policies of President Mbeki. The outcome of this looming struggle will show where the centre of gravity in the ANC now lies.

COSATU and the SACP are making no secret of their intention of seizing "working class hegemony in the State and in all centres of power" as the prelude to the establishment of a Marxist-Leninist state. Needless to say, any such move would be a fatal blow - not only to our Constitution and our democracy, but also to our economy and to any prospect for peace and stability.

The final threat to our Constitution is, perhaps, the most insidious of all. It is our own apathy. It is our unwillingness to support our Constitution actively, and to lay claim to the rights that it guarantees. All of us continue with our daily lives; we take our children to school; we contribute to the economy in our offices and factories; we 
entertain our friends; and we go on holiday. We seldom stop to think that virtually everything that we do, everything we own, everything to which we aspire, depends on the preservation of our Constitution and the freedom and rights that it guarantees. Somehow, we continue to regard the Constitution as something peripheral to our lives, something to which we need turn our thoughts only when the need arises.

We must shed this attitude. Our future happiness and prosperity and the future security of our children depends directly on the preservation of our Constitution. It is not something that people can simply delegate to this or that political party, or this or that civil society organisation. For evil to prosper, it is sufficient that good men should do nothing.

I call on you all, in the months leading to the commemoration of the twentieth anniversary of 2 February 1990, to take active steps to support the Constitution. Know what your rights are; claim them and insist that the equally valid rights of all other South Africans be respected; support organisations like the Centre for Constitutional Rights that are upholding the Constitution; make the Constitution a central part of your thoughts and of your lives - because, believe me, it really is. Support of the Constitution is not merely doing something for yet another good cause: it is the most appropriate and pressing protection of one's own core interests of which I can think. We are prepared to pay good money to insure our homes, our cars, our health and our lives. What are we prepared to do to ensure our future freedom, peace and prosperity?

Despite the warnings that I have given of the threats that confront our Constitution I remain an optimist. I am confident that many people in the ANC leadership share many of the concerns that I have expressed this evening. I am confident that the great majority of all our communities support the Constitution. All of us now need to join hands in celebrating the many good things that we have achieved together since 1990. All of us, equally, need to work together to address the many serious challenges that still confront us. 


\section{Bibliography}

\section{Register of legislation}

Constitution of the Republic of South Africa, 1996

Films and Publications Amendment Act 3 of 2009

Interim Constitution of the Republic of South Africa, 1993

National Prosecuting Authority Amendment Act 56 of 2008

South African Police Services Amendment Act 57 of 2008

\section{Register of government publications}

Constitution Fourteenth Amendment Bill GN 520 in GG 31013 of 8 May 2008

Constitution Seventeenth Amendment Bill GN 869 in GG 32311 of 17 June 2009

Expropriation Bill GN 440 in GG 30963 of 11 April 2008

Green Paper on National Strategic Planning, September 2009 